\title{
Dampak Dikeluarkannya Edik Milano 313 bagi Kebebasan Gereja
}

\author{
Jon Mister R. Damanik \\ Pascasarjana Magister Kepemimpinan Kristen, Sekolah Tinggi Teologi Erikson-Tritt, \\ Manokwari \\ jon18damanik@gmail.com
}

\begin{abstract}
Church history is not an outdated or outdated writing, but church history has an important role to play. Because in the history of the church there are important parts that can be used as a teaching for the church today. Chrestus is a term for followers of Christ, and Christians are used as an outlet for pleasure when they are persecuted, pitted against hungry animals, used as torches to light the garden, nearly 250 years of persecuted Christians have not been given freedom by the state even if there is a problem -problems like fire whose cause is Christians because they do not worship their gods so that the gods are angry. The Edik Milan is a decree issued in 313 which greatly influenced the church's freedom to carry out religious activities. The meaning of Edik is: "an order carried out by the ruler." Milan is "the Roman state where Roman rule ruled." With the issuance of this Edic of Milan by Konstantinu the Great, the ruler of the Roman empire gave a glimmer of hope in freedom of worship. Events that have occurred in the church in the past are a motivation for the church to keep carrying out the command of the Lord Jesus, namely to make all nations become His disciples. The church exists today because there was a church in the past, hope to continue learning about history because from history there will be a lot to know about what happened in the past as a positive lesson in the present.
\end{abstract}

Keywords: Edik Milan; church freedom; church history

\begin{abstract}
Abstrak: Sejarah Gereja bukan suatu tulisan yang tidak berlaku atau yang sudah usang, tetapi sejarah gereja memiliki peranan penting untuk dipelajari. Karena dalam sejarah gereja terdapat bagian-bagian yang penting untuk dapat dijadikan sebagai suatu pengajaran bagi gereja masa kini. Chrestus adalah suatu sebutan untuk pengikut Kristus, dan orangorang Kristen dijadikan sebagai pelampiasan kesenangan pada saat mereka dianiaya, diadu dengan binatang lapar, dijadikan obor sebagai penerang taman, hampir 250 tahun orangorang Kristen dianiaya tidak diberikan kebebasan oleh negara bahkan jika ada masalahmasalah seperti kebakaran yang penyebabnya itu adalah orang Kristen karena mereka tidak menyembah dewa mereka sehingga dewa murka. Edik Milan adalah suatu Surat Keputusan yang dikeluarkan pada tahun 313 yang sangat berpengaruh bagi kebebasan gereja untuk melaksanakan kegiatan ibadah-ibadah. Arti Edik adalah: "perintah yang dilakukan oleh penguasa." Milan adalah "negara Roma tempat pemerintahan Romawi berkuasa." Dengan dikeluarkan Edik Milan ini oleh Konstantinu Agung penguasa kekaisaran Romawi memberikan secercah harapan dalam kebebasan dalam melaksanakan ibadah. Peristiwa yang pernah terjadi pada gereja pada masa dulu adalah suatu motivasi bagi gereja untuk tetap menjalankan perintah Tuhan Yesus yaitu untuk menjadikan semua bangsa menjadi murid-Nya. Gereja ada pada hari ini karena ada gereja pada masa lalu, harapan teruslah belajar tentang sejarah karena dari sejarah akan banyak diketahui apa yang terjadi pada masa lalu sebagai suatu pembelajaran yang positif pada masa kini..
\end{abstract}

Kata kunci: Edik Milan; kebebasan gereja; sejarah gereja 


\section{PENDAHULUAN}

Sejarah gereja banyak memberikan kontribusi dalam pengetahuan tentang perkembangan gereja di bumi ini, sejarah gereja memaparkan dengan baik situasi dan kondisi alur perkembangan sejarah gereja mulai dari abad I hingga abad 20. Dan perlu untuk diketahui bahwa sejarah gereja memberikan nilai-nilai positif dalam untuk mengetahui jalan panjang sejarah yang benar-benar terjadi pada masa lampau yang masih baik untuk dipelajari pada masa kini.

Jika dipelajari dengan baik sejarah gereja jelaslah akan diketahui apa yang terjadi pada gereja pada masa lampau hingga pada masa kini. Mengapa gereja (jemaat) masih eksis hingga pada masa kini? Padahal tantangan yang dialami oleh gereja pada masa lampau begitu kerasnya. Tuhan Yesus pernah mengatakan kepada para murid-Nya yang terdapat dalam Matius 16:18 "Dan Aku berkata kepadamu: Engkau adalah Petrus dan di atas batu karang ini Aku akan mendirikan jemaat-Ku dan alam maut tidak akan menguasainya" ada dua kata penting yang dikatakan Tuhan Yesus dalam Matius 16:18. Pertama: "Di atas batu karang ini akan mendirikan Jemaat-Ku," "epi taute petra oikodomeso mou ten ekklesian." (di atas ini batu besar Aku akan mendirikan Ku jemaat)"1 ini adalah permainan kata yang dikatakan Tuhan Yesus "istilah Petrus (Petras nama yang umum untuk sebongkah batu karang) dan batu karang (petra segumpal batu karang) tubuh rohani. Jemaat yang disebutkan pertama kali dalam Alkitab dibangun berdasarkan fakta yang dinyatakan Tuhan mengenai Kristus yang diakui oleh Petrus yang dinyatakan Tuhan ketika orang dibuat sadar dan mengakui pribadi dan karya-Nya."2 Yang kedua adalah: "dan alam maut tidak akan menguasainya." (kai pulai adou ou katiskhusousin autes, dan pintupintu gerbang dunia orang mati tidak akan sanggup menguasainya.)"3 dalam tafsiran Wycliffe menjelaskan arti dari perkataan Tuhan Yesus ini sebagai berikut:

Dunia orang mati ...gerbang-gerbang neraka atau sheol yang dimaksudkan adalah pintu masuk menuju neraka, yang umumnya adalah kematian. Gereja Kristus yang diresmikan pada hari Pentakosta tidak akan tunduk pada kematian jasmaniah, sebab kebangkitan Tuhan merupakan jaminan kebangkitan orang percaya lebih khusus lagi orang-orang yang meninggal sebelum kebangkitan langsung berada bersama dengan Kristus, tidak menunju ke neraka (Ef. 4:8; Fil. 1:23; 2Kor. 5:8). ${ }^{4}$

Dari penjelasan ini jelaslah bahwa hingga pada masa lahirnya gereja (jemaat mula-mula) hingga sekarang gereja tetap eksis karena ada jaminan yang dijanjikan oleh Tuhan Yesus bagi gereja Nya.

Dalam penulisan jurnal dengan judul "Dampak Dikeluarkannya Edik Milano Bagi Kebebasan Gereja" ini sangat penting untuk diketahui dalam pertumbuhan gereja pada masa kini, dan mungkin masih banyak orang belum mengetahui apa dampak dikeluarkannya Edik Milan 313 bagi kebebasan gereja pada masa itu berarti sebelum dikeluarkannya Edik Milan gereja belum memiliki kebebasan dalam menjalankan peribadatan masa itu.

${ }^{1}$ Hasan Susanto, Perjanjian Baru Interlinier Konkordansi Jilid I (Jakarta: Lembaga Alkitab Indonesia, 2004), 92.

${ }^{2}$ The Wycliffe Bible Comentary (Malang: Gandum Mas, 2001), 79.

${ }^{3}$ Hasan Susanto, Perjanjian Baru Interlinier Konkordansi (Jakarta: LAI, 2004), 1:92.

${ }^{4}$ The Wycliffe Bible Comentary (Malang: Gandum Mas, 2001), 79. 


\section{Masa Sebelum Dan Sesudah Dikeluarkannya Edik Milan}

Bagian ini akan dijelaskan bagaimana keadaan gereja sebelum dikeluarkannya Edik Milan, ada pesan Tuhan Yesus kepada murid-murid-Nya sebelum Ia naik ke sorga seperti yang tertulis dalam Kisah Para Rasul 1:8 "tetapi kamu akan menerima kuasa, kalau Roh Kudus turun ke atas kamu, dan kamu akan menjai saksi-Ku di Yerusalem dan seluruh Yudea dan Samaria dan sampai ke ujung bumi." Janji Tuhan ini digenapi pada saat keturunan Roh Kudus (Kisah Para Rasul 2) selanjutnya lahirlah jemaat mula-mula yang dilakukan oleh para murid-murid Tuhan Yesus seperti yang Ia janjikan.

Jika dilihat dalam kitab Kisah Para Rasul secara keseluruhan yang mengisahkan sejarah panjang dari pelayanan para murid-murid Tuhan Yesus dan pelayanan para murid Tuhan Yesus tidaklah mulus tetapi banyak tantangan yang mereka hadapi dari orang-orang yang tidak menerima atau tidak percaya kepada Tuhan Yesus, seperti yang dialami oleh Stefanus salah seorang yang percaya kepada Tuhan Yesus mati syahid yang dilakukan oleh Mahkamah Agama dan orang-orang yang tidak menerima apa yang dikatakan oleh Stefanus sehingga Stefanus dilempari dengan batu hingga ia meninggal (Kisah Para Rasul 7:54-60). Selain itu pengaruh dari kepercayaan agama suku dan fisafat juga dari pemerintahan kekaisaran Romawi menjadi rintangan dalam perkembangan pelayanan gereja di muka bumi ini seperti:

\section{Penyembahan Kepada Berhala}

Bangsa-bangsa lain yang bukan bangsa Israel pada umumnya mereka sudah memiliki agama yang sudah lama mereka percayai seperti yang dijelaskan oleh Dietrich Khul:

Di Mesir, Persia dan Asia Kecil Turki) banyak agama berkembang yang kemudian juga dibawa ke daerah-daerah lain dikekaisaran Romawi misalnya penyembahan kepada Isis dan Osiris (berasal dari Mesir), penyembahan kepada Mithras (berasal dari Persia dan berkembang khususnya dikalangan militer) dan penyembahan kepada Kybele (berasal dari Asia Kecil). Perkembangan agama-agama itu dalam lingkungan kekaisaran Romawi mempunyai dua akibat. Pertama: penduduk-penduduk kekaisaran Romawi dapat membanding-bandingkan pelbagai agama dan menjadi biasa dengan munculnya dan berkembangnya agama-agama yang baru. Kedua: terjadinya percampuran agama. Dewa-dewa tertinggi pelbagai agama disamakan seperti: Zeus (Yunani) Yupiter (Roma) Ahura Mazda (Persia) Marduk (Babilonia Irak) dianggap sama demikian kesadaran akan monotheisme berkembang dan menyiapkan jalan untuk kepercayaan kepada Allah yang Maha Esa. ${ }^{5}$

Ini jelas kan menjadi suatu tantangan yang dihadapi oleh para murid-murid Tuhan Yesus bahkan para orang percaya pada masa itu, apalagi agama-agama ini sudah lama dipercayai oleh bangsa-bangsa dan mereka sudah merasakan aman dan tenang dengan kepercayaan dan tuntutan agama mereka itu. Seperti yang dijelaskan dalam kitab Kisah Para Rasul 19:21-4, Paulus menghadapi para orang-orang di Efesus yang sudah lama mempercayai kepada "dewi Artemis" ayat 24 "sebab ada

${ }^{5}$ Dietrich Khul, Sejarah Gereja Mula-Mula Yunani - Romawi 30-500 (Batu: Yayasan Persekutuan Pekabran Injil Indonesia (YPPII),1998), 32-33. 
seorang bernama Demetrius, seorang tukang perak, yang membuat kuil-kuilan dewi Artemis dari perak. Ayat 26 mengatakan:"sekarang kamu sendiri melihat dan mendengar bagaimana Paulus, bukan saja di Efesus, tetapi juga hampir di seluruh Asia telah membujuk dan menyesatkan banyak orang dengan mengatakan, bahwa apa yang dibuat tangan manusia bukanlah dewa. Ayat 28 "mendengar itu meluaplah amarah mereka, lalu mereka berteriak-teriak katanya:"Besarlah Artemis dewi orang Efesus." (Artemis: dewi perbuaruan, alam liar, hewan liar, perawan dan pembuktian dia adalah pembawa dan penghalau penyakit pada perempuan serta merupakan dewi penolong kelahiran. Artemis merupakan anak dari Zeus dan Leto saudari kembar dari Apollo).

Penjelasan ini menerangkan bahwa pengaruh agama-agama yang dipercayai oleh bangsa-bangsa pada saat itu mereka tidak mau diganggu oleh ajaran-ajaran baru, sehingga pada saat Paulus memberitakan Injil di Efesus ada orang-orang yang tidak menerima karena mereka telah kuat dalam kepercayaan lama mereka.

\section{Pengaruh Filsafat}

Bagian berikut yang perlu juga untuk dijelaskan adalah pengaruh filsafat, pengaruh filsafat dari Plato dan Aristoteles, ajaran filsafat ini sudah lama berkembang dikalangan orang-orang Yunani. Rasul Paulus pernah menasehati kepada Timotius tentang pengaruh ajaran filsafat ini dalam I Timotius 6:20 "Hai Timotius, peliharalah apa yang telah dipercayakan kepadamu. Hindarilah omongan yang kosong dan yang tidak suci dan pertentangan-pertentangan yang berasal dari apa yang disebut pengetahuan." Dari penjelasan ini bahwa di Efesus telah (sudah) berkembang ajaran yang disebut pengetahuan (filsafat). Apa arti dari filsafat? Filsafat adalah: "pengetahuan dan penyelidikan dengan akal budi mengenai hakikat segala yang ada, sebab, asal, dan hukum; teori yang mendasari alam pikiran atau suatu kegiatan; ilmu yang erintikan logika estetika, metafisika dan epistemology."6 Arti pengertian dari filsafat ini, sangat jelas bahwa pada umumnya manusia akan menggunakan akal untuk membuktikan, menganalisa segala sesuatu.

Dan dalam tulisan ini akan dijelaskan pengaruh ajaran filsafat dalam penafsiran tentang ajaran Kristen dan butuh kehati-hatian dalam menerima atau mempelajari dari ajaran ini.

Plato (427-347 s. M). Berbicara tentang tokoh filsuf ini, bukan sesuatu yang baru, dikalangan pendidikan filsuf Plato sangatlah terkenal karena Plato memberikan gagasangagasan dalam pemikiran. Pandangan Plato tentang Allah. Allah berada jauh tak terhingga di atas dunia dan manusia. Tetapi daripadanya mengalir roh-roh dalam jumlah yang tak terbatas. Seseorang yang pandai dapat menangkap roh itu melalui rohnya sendiri karena roh manusia berasal dari Allah. Dunia yang kita pandang ini terletak diperbatasan antara terang dan gelap. Jiwa atau roh manusia hanya dapat masuk kesana melalui askese.

Plato memberikan suatu buah pikiran tentang keberadaan Allah dan manusia, Allah menurut Plato ada disuatu tempat yang jauh yang tidak dapat dipikirkan oleh

${ }^{6}$ Kamus Besar Bahasa Indonesia (Jakarta: Gramedia Pustaka Abadi, 2008), 392. 
manusia. Manusia hanya dapat mengenal Dia melalui rohnya karena roh manusia berasal dari roh Allah. Kesimpulannya bahwa Allah itu tidak ada hubungan dengan manusia karena dibatasi oleh jarak.

Stoa. Pendiri aliran filsafat Stoa adalah Zeno (336 -264 s.M) yang mengajarkan bahwa: "Allah dan dunia adalah satu saja (Pantheisme) Allah mengalir dalam semuanya, Ia berada dalam semuanya, Kuasa Allah terdapat di dalam semuanya dan menggerakkan semuanya, di dalam dia dan oleh dia manusia hidup. Singkatnya bahwa menurut aliran Stoa ini Allah dipandang identik dengan alam. Kesimpulannya adalah, bahwa Allah berada di dalam Alam dan Allah itu dapat dikenal atau dipercayai melalui alam.

Epikuros. Pendirinya adalah Epikur (341-270 s.M) Epikur dalam pandangannya mengatakan: "menjunjung tinggi kesenangan hati (minumlah, makanlah dan senangkanlah hatimu karena besok anda akan meninggal) namun kesenangan bukanah identik dengan hawa nafsu namun terutama dilihat dan dirindukan dalam kesejahteraan jiwa yang bebas dari tahyul dan ketakutan; ketenagan batin yang dirindukan diancam oleh ketakutan yaitu ketakutan terhadap murka para dewa terhadap maut dan nasib tujuan hidup adalah hedone (kenikmatan dan kepuasan)yang tercapai jikalau batin tenang dan tubuhnya sehat."7

Apa yang dikatakan oleh Epikur dalam ajarannya yang dikenal dengan Epikurus mengajarkan tentang "Hedonisme" berhubung karena manusia itu pada intinya mengalami ketakutan terhadap dewa-dewa, maka menurutnya manusia dapat saja melakukan apa yang ia inginkan yaitu untuk menyenangkan jiwa dan pikirannya.

Tiga tokoh filsafat yang telah mengajarkan ajarannya mereka lebih kurang 300 - 400 tahun sebelum Kristus ada (BC) jelaslah bahwa ajaran ini telah berkembang dan diikuti oleh orang-orang pada saat itu yang menjadi suatu pegangan hidup bagi mereka.

\section{Lahirnya Gereja Di Bawah Kekuasaan Kekaisaran Romawi}

Pada masa sebelum dan kelahiran Yesus Kristus ke dalam dunia ini. Pemerintah kekaisaran Romawi menguasai bumi ini secara khusus juga di Israel. Jajahan Romawi dapat dipersatukan melalui hubungan yang baik antara segala propinsi kerajaannya seperti kaisar Agustus (Lukas 2:1-3). Agustus Caesar, kaisar pertama dari Kemaharajaan Romawi adalah salah satu orang yang paling bersemangat yang pernah hidup. Dalam tengkoraknya yang berbentuk segi tiga yang padat itu, ia memiliki lebih banyak kemampuan daripada yang dimiliki sekelompok orang biasa. Menurut para ahli sejarah, namanya sejajar dengan Konstantin yang agung sebagai salah seorang pemimpin Kemaharajaan Romawi yang paling kreatif. Dan meskipun Roma mengalami masa jaya terbesar dibawah pemerintahannya, ia memulai hidupnya yang gemilang ketika ia masih seorang remaja canggung berusia 18 tahun."8

${ }^{7}$ Khul, Sejarah Gereja Mula-Mula Yunani - Romawi 30-500, 37-38.

${ }^{8}$ Charles Ludwig, Para Penguasa Pada Zaman PB (Bandung: Kalam Hidup, 2007), 26-27. 
Pemerintahan Romawi juga adalah bagian atau tantangan pada waktu berdiri jemaat Tuhan. Kenapa?

1. Orang Kristen dianggap mazhab (aliran) Yahudi. (apakah bangsa Yahudi Kristen?).

2. Orang Kristen tidak menyembah kepada berhala atau kepada patungpatung kaisar.

3. Orang Kristen dianggap sebagai pembangkang karena mulai tidak taat kepada perintah Kaisar.

4. Orang Kristen dianggap sebagai biang dari segala masalah (misalnya jika ada bencana alam yang disalahkan adalah orang Kristen, dengan anggapan bahwa para dewa murka karena mereka tidak menyembahnya lagi).

Pada masa pemerintahan kekaisaran Romawi melalukan penghambatan terhadap gereja-gereja, dengan alasan-alasan tersebut di atas. Firman Allah menceritakan perkembangan Jemaat mula-mula dalam kitab Kisah Para Rasul, dalam kitab ini dijelaskan bahwa para murid-murid Tuhan Yesus terus memberitakan Injil kepada semua orang. Jika dilihat dalam Kisah Para Rasul 2:1-47. dan setelah Pentakosta para murid memberitakan Injil kepada mereka yang belum percaya sesuai dengan Kisah Para Rasul 1:8 berkata: "Tetapi kamu akan menerima kuasa, kalau Roh Kudus turun ke atas kamu, dan kamu akan menjadi saksi-Ku di Yerusalem dan di seluruh Yudea dan Samaria dan sampai ke ujung bumi." Dapat dikatakan bahwa penggenapan nubutan Tuhan Yesus tentang jemaatnya telah digenapi dengan lahirnya jemaat-jemaat Tuhan dalam Kitab Matius 16:18.

Pada zaman-zaman pemerintahan raja-raja yang berkuasa pada masa itu, selalu mementingkan politik dan mereka lebih fokus untuk menyenangkan diri mereka, pada masa pemerintahan raja Kladius antara tahun 41-45 Masehi bahwa agama Kristen itu dianggap sebagai pengacau "bahwa agama Kristen mulai dianut oleh orang-orang Yahudi di Roma pada waktu itu sudah diketahui benar namun ada catatan Suetonius yang menambahkan tekanan karena orang-orang Yahudi di Roma selalu meimbulkan kekacauan atas hasutan Chrestus (Kristus), ia Klaudius mengusir mereka dari kota itu."9

Tetapi yang lebih kejam diantara semua raja yang pernah memerintah Roma adalah Nero mengapa? Ini faktanya!

Bayang-bayang hitam mulai menutupi bukit-bukit sepanjang kota Roma Ketika budak-budak belian mencanangkan salib-salib yang terakhir dalam taman-taman Nero yang sangat indah, sementara mereka bekerja, prajurit-prajurit menggiring orang-orang Kristen dan mengikat atau memaku mereka pada salib-salib itu lalu para prajurit itu menyiram mereka dengan aspal yang mudah terbakar. Sering perlombaan kereta yang diselenggarakan atas perintah kaisar harus dihentikan karena hari sudah gelap, malam itu keadaannya sangat berbeda orang-orang Kristen yang dibakar akan menyediakan penerangan. ${ }^{10}$

${ }^{9}$ Ludwig, Para Penguasa Pada Zaman PB, 87.

${ }^{10}$ Ibid., 91. 
Nero adalah mesin pembunuh terhadap orang-orang Kristen, demi untuk menyenangkan hatinya atau menyenangkan rakyatnya, Nero adalah seorang kaisar yang sangat kejam, seperti yang dijelaskan berikut ini

Karena Nero melihat bahwa ia telah menimbulkan rasa tidak senang pada orang banyak, ia tidak pernah mengulangi pertunjukkan ini, sebagai gantinya, ia memuaskan dirinya dengan melemparkan orang-orang Kristen ke kandang Singa atau mengadu mereka dengan anjing-anjing setelah mereka dipakaikan kulit hewan atau dengan membunuh orang-orang Kristen warga negara Roma dengan pedang. ${ }^{11}$

Apa yang menyebabkan sehingga orang-orang Kristen dimusuhi atau mereka dianiaya?

1. Kristen dianggap sebagai Mazhab Yahudi.

2. Agama-agama baru tidak mendapat ijin dari pemerintah Romawi.

3. Orang Kristen menjauhkan dari bentuk-bentuk pencemaran, seperti: penyembahan berhala, persundalan, sandiwara, gelanggang pertarungan antara manusia dengan manusia, binatang, tidak mau menjadi prajurit.

4. Perjamuan Kudus ada anggapan dari mereka yang tidak percaya bahwa pada waktu melaksanakan Perjamuan Kudus, jemaat Tuhan memotong/menyembelih seorang anak kecil, dengan alasan Tubuhnya di makan, dan darahnya diminum (Mat. 26:26-28)

5. Orang Kristen dianggap hidup dalam perzinahan karena ada kata "cium kudus" (1 Ptr. 5:14)" Berilah salam seorang kepada yang lain dengan cium yang kudus. Damai sejahtera menyertai kamu sekalian yang berada dalam Kristus. Amin."

6. Orang Kristen tidak membakar dupa untuk menyembah kaisar, sehingga ada asumsi bahwa orang Kristen tidak setia kepada negara.

7. Orang Kristen dianggap sebagai sebab musabab bencana alam, dengan alasan bahwa orang Kristen tidak menyembah kepada Kaisar sehingga dewa murka.

Yang lebih menyedihkan pada masa pemeritahan Nero adalah pada saat ia membakar kota Roma sehingga api tidak padam selama enam hari yang menghancurkan kota Roma, penyebab kebakaran itu dituduhkan kepada orang Kristen sehingga banyak orang Kristen di Roma dihukum mati secara kejam yang luar biasa. "Nero kaisar Romawi yang berpikir bisa bisa memusnahkan kekristenan dengan membunuh orang-orang Kristen."12

Berikut ini daftar para kaisar yang sangat membenci orang-orang Kristen pada abad pertama. Jemaat-jemaat banyak mengalami tantangan-tantangan atau masalah-masalah yang muncul dari mereka yang membenci ajaran Kristen. Dunia pada masa itu dikuasai oleh Romawi. Maka para kaisar Romawi ingin membinasakan Kristen dengan cara menganiaya, membunuh, membakar, memenjarakan, orang-orang Kristen seperti pada zaman:

${ }^{11}$ Ludwig, Para Penguasa Pada Zaman PB, 92

12Dennis J. Mock, Survei Sejarah Gereja (Atlanta: Gorgia, 1989), 45. 
1. Nero (54-68 SM) membakar kota Roma dan dtuduhkan kepada orang Kristen, sehingga orang Kristen mengalami banyak masalah.

2. Domitiamus: (81-96 SM) pemerintahannya mengasingkan Yohanes ke Pulau Patmos.

3. Trajanus (98-117 SM).

4. Hadrianus (117-138 SM).

5. Marcus Aurelius (161-180 SM).

6. Septimius Severus (193-211 SM).

7. Maximin (235-238 SM).

8. Decius (249-251 SM) penganiayaan yang luar biasa

9. Valerianus (235-260 SM)

10. Deocletianus (248-305 SM) para pemerintahan ini, jemaat banyak juga mengalami penganiayaan, dan semua gereja ditutup.

Dan jika dilihat dalam buku-buku sejarah yang menjelaskan penganiayaan yang hebat yang dilakukan oleh para penguasa kekaisaran Romawi terhadap orangorang Kristen seperti yang dialami oleh para murid-murid Tuhan Yesus yang juga mati syahid demi mempertahankan iman kepada Yesus Kristus.

\section{Gereja Pada Masa Pemerintahan Kaisar Konstantinus Agung}

Setelah dijelaskan masa-masa sulit yang dialami oleh orang-orang Kristen mulai dari tahun 54 - 305 Masehi, untuk membuktikan itu hanya bisa dilihat dari sejarah, mengapa orang Kristen dimusuhi? Firman Allah mengatakannya: Tertulianus mengatakan: "Darah orang Martir itu adalah Benih Gereja"13

Yohanes 12:24 "Aku berkata kepadamu: Sesungguhnya jikalau biji gandum tidak jatuh ke dalam tanah dan mati, ia tetap satu biji saja; tetapi jika ia mati, ia akan menghasilkan banyak buah. 12:25 Barangsiapa mencintai nyawanya, ia akan kehilangan nyawanya, tetapi barangsiapa tidak mencintai nyawanya di dunia ini, ia akan memeliharanya untuk hidup yang kekal. 12:26 Barangsiapa melayani Aku, ia harus mengikut Aku dan di mana Aku berada, di situ pun pelayan-Ku akan berada. Barangsiapa melayani Aku, ia akan dihormati Bapa.

Selanjutnya akan dibahas seorang kaisar yang memberikan secercah harapan dalam perkembangan dan kebebasan gereja dalam melaksanakan kegiatannya; ialah Kaisar Konstantinus Agung. Siapa kaisar Konstaninus Agung? Konstantinus Agung anak dari Konstantinus Klorus seorang perwira tentara Romawi yang juga menjadi kaisar menggantikan Maximin dan ibunya bernama Helena, lahir 27 Pebruari 272 di kekaisaran Romawi. Salah satu Kaisar Romawi yang menganut agama Kristen.

Dalam judul penelitian "Dampak dikeluarkannya Edik Milan Bagi Kebebasan Gereja” dimulai dari Gerakan dari Konstantinus Agung, setelah Konstantinus Agung dapat mengalahkan Maxentius putra kaisar Maximin pada tahun 312 Masehi. Setelah kaisar Romawi Konstantinus Agung resmi menjadi kaisar ada suatu

13Th Van Den End, Harta Dalam Bejana (Jakarta: BPK Gunung Mulia, 2009), 50. 
perubahan besar yang dilakukannya yaitu Konstantinus Agung mengeluarkan suatu Surat Keputusan yang dikenal dengan "Edik Milan 313" adapun kutipan dari "Edik Milan" yang berisikan keputusan-keputusan kaisar yang isi kutipan dari Edik Milan 313 itu adalah: "Gereja mendapat kebebasan penuh untuk beribadah; kekristenan menjadi salah satu agama di dalam kekaisaran Romawi; seluruh milik gereja yang telah disita oleh pemerintah Romawi harus dikembalikan kepada gereja dan semua kerugian diganti."14

Perlu juga untuk diketahui mengapa Konstantinus Agung membela gereja? Atau pertanyaan lain apa yang menyebabkan sehingga kaisar Konstantinus Agung bisa berbalik arah tidak seperti kaisar-kaisar yang mendahuluinya? Th Van Den End menjelaskan: "Terbetik cerita bahwa Konstantinus, sebelum memulai pertempuran untuk merebut takhta di Roma (312) ia melihat sinar terang berbentuk salib di langit disertai perkataan: dengan tanda ini engkau akan menang" 15 Ini adalah pertempuran dengan Maxentius putra dari Maximin. Akhirnya sebelum wafat Konstantinus Agung minta dibaptis dan menjadi kaisar Kristen pertama dalam sejarah dunia." 16

Perlu untuk diketahui bahwa semasa pemerintahan kaisar Konstantinus Agung yang memerintah Romawi, gereja mendapatkan hak yang sama dengan agama-agama lain yang ada di kerajaan Romawi, gereja tidak mendapat ancaman dari pihak manapun dan pengikut agama Kristen tidak lagi merasakan ketakutan untuk melaksanakan ibadah-ibadah di dalam gereja karena telah ada jaminan atau kekuatan hukum dari pemerintah Romawi, gereja telah bebas dari segala tuduhan yang selama ini dirasakan oleh gereja.

Dietrich Khul mengatakan: Pada fase 313-380 kaisar dan pemerintah kekaisaran Romawi memihak kepada gereja kenyataan ini menyebabkan banyak orang masuk gereja berdasarkan pertimbangan politik. Perkembangan ini tidak hanya menguntungkan gereja kaisar-kaisar mengingatkan suatu gereja yang esa dan kuat yang mereka butuhkan untuk mempersatukan bangsa dan negara. Oleh pertimbangan-pertimbangan politik ini kaisar Konstantinus sering mencampuri urusan-urusan gereja, ia membasmi bidat Montanisme, dan Novatianisme."17

Ada beberapa dampak dari keputusan "Edik Milano 313"

1. Memberikan hak sepenuhnya kepada gereja untuk melaksanakan visi dan misi gereja, yaitu untuk memberitakan Injil ke seluruh dunia.

2. Gereja mendapatkan perlindungan dari pemerintah.

3. Gereja bebas melakukan ibadah-ibadah tanpa ada intimidasi dari pihak manapun.

4. Gereja diikutkan dalam setiap pembahasan (konsili) yang ingin menyesatkan pengajaran kekristenan.

${ }^{14}$ Dietich Khul, Sejarah Gereja Mula-Mula Yunani - Romawi 30-500 (Batu: Yayasan Persekutuan Pekabran Injil Indonesia (YPPII)1998), 66.

15Th Van Den End, Harta Dalam Bejana, 52.

${ }^{16}$ Khul, Sejarah Gereja Mula-Mula Yunani - Romawi 30-500, 66.

${ }^{17}$ Ibid., 67. 


\section{Kekaisaran Romawi pertama menjadi negara mayoritas Kristen.}

Dengan dikeluarkannya "Edik Milano" ini memberikan kesempatan seluasluasnya bagi gereja, yang dahulunya gereja mendapatkan berbagai ancaman dan penganiayaan tetapi dengan keputusan Edik Milan ini gereja kuat karena memiliki jaminan keamanan dari pemerintah.

Jika ditelusuri mulai dari tahun 313 Masehi adalah langkah awal bagi gereja Tuhan untuk dapat bebas melakukan kegiatan pelayanan dan untuk menjalankan misi Tuhan Yesus dalam amanat agung Matius 28:19-20 Karena itu pergilah, jadikanlah semua bangsa murid-Ku dan baptislah mereka dalam nama Bapa dan Anak dan Roh Kudus, dan ajarlah mereka melakukan segala sesuatu yang telah Kuperintahkan kepadamu. Dan ketahuilah, Aku menyertai kamu senantiasa sampai kepada akhir zaman."

Walaupun kedepan masih banyak yang dihadapi oleh gereja seperti ajaranajaran Gnostic, Montanisme, Sabelianisme, Manikhenisme dan Arianisme yang menafsirkan tentang Allah Tritunggal dengan konsep filsafat. Semua itu dapat dilalui karena Kristus adalah kepala gereja yang menyertai gereja hingga akhir zaman.

\section{KESIMPULAN}

Sejarah Panjang lahirnya dan pertumbuhan gereja di muka bumi ini mengalami banyak tantangan yang dilakukan oleh orang-orang yang tidak percaya kepada Kristus berusaha untuk membinasakan para pengikut Tuhan Yesus dengan cara yang keji, pembunuhan, penyiksaan, diadu dengan binatang buas tidak menyurutkan iman percaya mereka kepada Tuhan Yesus, malahan gereja pada masa itu berkembang dengan pesat seperti ada istilah "semakin dibabat semakin merambat" dan seperti pernyataan Tertullianus yang mengatakan:"Darah Mati Syahid adalah benih gereja" maka gereja dari dulu hingga sekarang ini dapat berjalan dengan baik karena ada jaminan yang diberikan Tuhan Yesus kepada gereja-Nya seperti yang pernah Ia sampaikan kepada murid-murid-Nya dalam Matius 16:18 "Dan Aku pun berkata kepadamu: Engkau adalah Petrus dan di atas batu karang ini Aku akan mendirikan jemaat-Ku dan alam maut tidak akan menguasainya."

Edik Milano 313 yang dikeluarkan oleh Konstantinus Agung penguasa kekaisaran Romawi sebagai suatu tonggak sejarah yang tidak dapat dilupakan, karena Edik Milano ini mengubah era pemerintahan di Kekaisaran Romawi dari yang menolak dan menganiaya orang-orang Kristen menjadi menghormati dan mengikuti ajaran-ajaran Kristen. Apa yang dibuat oleh Konstantinus Agung bukan suatu kebetulan tetapi semua adalah waktu Tuhan bagi gereja-Nya di muka bumi. Kita tahu sekarang, bahwa Allah turut bekerja dalam segala sesuatu untuk mendatangkan kebaikan bagi mereka yang mengasihi Dia, yaitu bagi mereka yang terpanggil sesuai dengan rencana Allah (Rom. 8:28); dan Roma 11:36, "Sebab segala 
sesuatu adalah dari Dia, dan oleh Dia, dan kepada Dia: Bagi Dialah kemuliaan sampai selama-lamanya."

\section{KEPUSTAKAAN}

Alkitab "Jakarta:LAI, 2008

End, Th Van Den. Harta Dalam Bejana. Jakarta: BPK Gunung Mulia, 2009.

Kuhl, Dietrich. Sejarah Gereja Mula-Mula Dalam Lingkungan Kebudayaan YunaniRomawi 30 - 500. Batu: Yayasan Persekutuan Pekabran Injil Indonesia (YPPII), 1998.

Kamus Besar Bahasa Indonesia. Jakarta: Gramedia Pustaka Abadi, 2008.

Ludwig, Charles. Para Penguasa Pada Zaman Perjanjan Baru. Bandung: Kalam Hidup, 2007.

Mock, J. Dennis. Survei Sejarah Gereja. Atlanta: Gerogia, 1989.

Susanto, Hasan. Perjanjian Baru Interlinier Konkordansi. Jilid I. Jakarta: LAI, 2004. Tafsiran Alkitab Masa Kini 3 Matius-Wahyu. Jakarta: OMF, 1996

Wicliffe Bible Comentary. Malang: Gandum Mas, 2001. 